\title{
IMPACT OF COVID-19 ON SUPPLY CHAIN MANAGEMENT
}

\author{
Dilek ULUCAN ERKESIMM \\ Istanbul Commerce University, Turkey \\ Received: February 04, $2021 \quad$ Accepted: March 02, $2021 \quad$ Published: May 01, 2021
}

\begin{abstract}
The competition between companies increases day by day with the change of customer demands and requirements. This competition is no longer between companies, it has started to occur in the networks in which companies are located. At this point, the importance given by companies to activities in their supply chain has increased. Due to the current Covid-19 pandemic, a number of problems have occurred in the supply chain management of companies. Covid-19 drove the whole world into a major crisis. Many sectors have suffered from economic collapse due to the pandemic. Therefore, firms faced with an imbalance between supply and demand. In this context, the aim of the study is to reveal conceptual evaluations about supply chain management and to present how and in what way companies are affected by the Covid19 pandemic.
\end{abstract}

Keywords: Supply Chain Management, Covid-19, Pandemic, E-Supply Chain

\section{Introduction}

In the competitive environment created as a result of globalization, companies achieve their success not only with their own organizations but also with the entire supply chain. In the developing world, businesses have understood the importance of supply chain management to improve processes and increase profit margins. In this way, while satisfying the target customer group, they find the opportunity to reduce costs and evaluate assets well. This is accelerated by the developing technology and web services. All businesses indicate the influence of supply chain management, albeit to varying degrees. (Charles, 2003: 3)

The value chain included various processes from the procurement of raw materials to the end user in products and services. Today, the business philosophy known as supply chain management consists of process, suppliers, customers, consumers and other supporting businesses. In this respect, supply chain management is directly related to information technologies, raw material supply, relations between businesses, strategies, and cultural formation(Çengel, 2008: 99).

The reason why supply chain management has suffered today is the Covid-19 pandemic that has left deep wounds in the world. In addition to posing a major health threat, companies are trying to cope with the pandemic. The measures taken to prevent further transmission of this pandemic negatively affect the activities in the supply chain, individual consumption habits, production processes and employment. When we look at the world in general, the pandemic deeply affected the global economy, as well as restrictions imposed for Covid-19 have caused an unprecedented decline in retail sales and store traffic. In this study, first of all, literature on supply chain management has been reviewed and e-supply chain dimensions have been evaluated. Afterwards, the effects of the Covid-19 pandemic on the supply chain were revealed.

\section{Literature Review}

This section reviews related literature of the study that was written by other researchers. Supply Chain Management, E- Supply Chain and Covid-19 pandemic are examined in detail.

\subsection{Supply Chain Management}

Supply chain management is defined as the integration of all business processes that add value to customers and other stakeholders in the chain such as product, service and information sharing in a supply chain that continues from the end customer to the main suppliers (Douglas, 1998).Supply chain management refers to inter-business relations and cooperation and the entire activities including the process of the arrival of raw material procured from 
2nd degree supplier to 1 st degree supplier, becoming a semi-finished product or a product in the manufacturer, delivery to the customer with the distributor logistics companies in between and finally transferring from customer to end user. (Koçoglu,2010: 98).

Today, supply chain management has become an important tool in the planning of many production and service businesses (Ungan, 2011: 65). There is a supply chain management that constantly renews itself depending on the developments. Concerning supply chain management, concepts such as Lean Supply Chain Management, Agile Supply Chain Management, Reverse Supply Chain Management and Green Supply Chain Management have recently emerged.

Supply chain management generally covers the following topics: purchasing, procurement, logistics and transportation, stock control, production planning and control, facility planning, outsourcing, marketing, organizational behavior and relationship management, contracts, information systems, network design, performance. measurement, etc. Methods such as mathematical modeling, optimization and game theory are used to solve problems in these subjects. (Aktas, 2010: 46).

The key features of supply chain management can be defined as follows:

- The supply chain includes all processes for the manufacture of goods and services, from manufacturers to consumers.

- In order to satisfy consumer needs, the supply chain requires the involvement of all players, directly and indirectly.

- Distribution service providers (carriers, warehouse managers, etc.), retailers and consumers contribute to the supply chain, not only to the relationship of the manufacturer and supplier, but also to all stakeholders.

- By commodity (raw material, semi-finished, finished part), information and money flow, each stage is interconnected.

- The supply chain requires the inclusion of all functions (new product development, Marketing, operations, distribution, Finance and customer service).

All these characteristics include both internal and inter-business process-oriented thought and the subsequent development of an organisational framework. The goal of the supply chain should be to optimise all the value that is produced. The value produced in the supply chain is the difference between what is provided for the consumer by the value of the finished product and the cost of the supply chain to meet customer needs. The relationship model that prioritises mutual benefit, rather than the conventional confrontational attitude, between the supplier and the consumer, is the fundamental concept in the supply leg of effective chain management. Businesses minimise the number of suppliers and costs with a long-term partnership strategy and achieve competitive advantage in foreign markets by building an environment of confidence (Erdal, 2011:11).

\subsection{E-Supply Chain}

The basic condition for the success of supply chain management is the effective sharing of fast and accurate information on departments such as procurement, production, marketing and logistics. Kulkarni (2001) defined internet-based supply chain management as the establishment of the system on internet that enables the supply of raw materials used in production, the transportation of these materials to the production points, and the delivery of the manufactured products to the customers. Internet-based supply chain management will make a significant contribution to the regulation of stocks, production plans, logistics plans, optimal use of resources and reduction of costs in response to changes in the market (Lancioni et al. 2000: 98). Accordingly, internet-based supply chain management will play an important role in the development of communication and cooperation between businesses that are independent from each other in the process from the supply of raw materials to the realization of production and presentation to customers. At the same time, the fact that the internet gives the opportunity to know and control the businesses on the supply chain provides a more successful implementation of supply chain management (Tanyeri ve Barutçu, 2003: 76).

Internet, which is an important force for the development of supply chain management, enables businesses to reduce their costs and increase their efficiency. The availability of a real-time communication opportunity between the enterprises in the supply chain, the timely ordering of raw materials to meet the demand, has enabled the reduction of stock costs and, in a sense, working with virtual stocks (Lancioni et al., 2003: 56). It has been determined that the 
internet contributes to the integration of businesses by providing the necessary information flow for the coordination of business activities. At the same time, the internet has contributed to the functioning of the market mechanism such as price competition and provided the opportunity to purchase some products at lower prices. (Schmelz vd., 2001: 10).

\subsection{Covid-19 Pandemic}

Given the past of the planet, epidemics have a global impact. Management and life variations are caused by them. In several instances, from diet to architecture and particularly the destruction of civilizations, outbreaks in history have been accepted as the cause of new innovations. After the Spanish Flu, Covid-19 is the first infectious disease outbreak that the entire world has experienced. A group of doctors led by Dr David Tyrrell in England performed several analyses on the common cold in 1965. They based on a virus that in tissue culture appears to be new and studied it under an electron microscope in detail. They discovered that this virus was very similar in the 1930 s to the virus isolated from bronchitis chickens. The ability of coronaviruses to infect humans has now been demonstrated for the first time with the discovery of this virus (Aysan, 2020: 21).

On December 31, 2019, the World Health Organization China Country Office confirmed cases of pneumonia, the cause of which is not currently known, in Wuhan, China's Hubei province. A new coronavirus that had not been observed in humans before was identified on January 5, 2020. Covid-19 was later named for this disorder, which was first called 2019-nCoV. It gradually infected the entire world three months after it was found in China (WHO, 2020). In a press release released on March 13, 2020 by the World Health Organisation, General Director Dr. Tedros Adhanom delivered a speech on the pandemic of Ghebreyesus. In order to reduce Covid-19's rate of spread, he said the following; "You can't fight a virus that you don't know where." To split the COVID-19 spread chain, detect, isolate, test and treat! The propagation of the disease will be constrained by any case we identify and treat." The use of the term is descriptive about the direction the disease will follow. (Üstün, 2020: 143).

The outbreak of Covid-19 has now become a global pandemic. Not only is this epidemic medical. It has created a variety of social, professional, political, economic, ethical and moral implications. Due to the fact that the world is not prepared for the Covid-19 epidemic, some delays and misunderstanding exist in the steps to be taken, the epidemic spread has been calculated to become a pandemic (Üstün, 2020: 147).

\section{Effects of Covid-19 Pandemic on The Supply Chain}

It is not possible to compare the effects of the coronavirus pandemic with other global crises such as the 2008 financial crisis. Because Covid-19, besides being a global epidemic, did not focus on low and middle-income countries. Interest rates are the lowest interest rates seen in the historical period. Countries of the world are more connected and integrated with each other. The current crisis has spillover effects along supply chains and there is also a simultaneous supply and demand shock. Unfortunately, the economic effects of Covid-19 are felt seriously in sectors and countries. When we look at the global effects, automobile manufacturers such as Volkswagen and Ferrari have suspended production in Europe. Key sectors that make up almost a quarter of a country's GDP, such as transportation, entertainment, retail, hotels and restaurants, have suffered seriously. Dow Jones lost 2,977 points on March 16, 2020, recording its worst one-day drop. Tourist attractions such as Paris, Madrid, Venice and Rome were abandoned, trade fairs and events were canceled. Public meetings and sports events have been canceled, and land, sea and air transportation have ceased until May. Millions of people lost their jobs in China, all of the hundreds of movie theaters in Canada were closed. (Cinel, 2020: 128).

Companies producing luxury goods stopped production, and Switzerland opened its doors only to its citizens, residents and vehicles after the pandemic. There are still too many uncertainties and question marks regarding Covid19. Available data show that Covid-19 is more contagious than SARS. On the other hand, Covid-19 has a much lower mortality rate (between 2-4\%) compared to SARS (10\%), and both had a much lower mortality rate than bird flu $(60 \%)$ (Chou vd., 2004: 42).

The human factor directly affects the supply and demand side of the supply chain. For this reason, the COVID-19 pandemic has had an impact on all sectors, especially health, agriculture, food, transportation, logistics, education and tourism. Due to many factors such as quarantine, illness, closed schools and curfew, people in many parts of the world cannot go to work and cause supply-side problems. This situation caused factory closures in industries such as technology, automotive, depending on the shortage of raw materials and semi-finished products (Yildiz, 2020:65). 
Similar effects that Covid-19 shows in all the world supply chain are also seen in Turkey. At the time of the first occurrence of the Covid-19 virus, reports containing positive economic forecast with the possibility of production shifting from China to Turkey reversed with the spread of the virus and finally seen in our country. The global structure created in supply chains also showed its effects in Turkey. The supply-side situation of the supply chain for manufacturing companies caused many sectors, especially automobile companies, to suspend their production due to the shortage of raw materials and spare parts. Firms have tried to reduce the number of workers with practices such as shift reduction, unpaid leave, etc. Those who have suitable machinery have started to produce products such as respirators and masks that are needed in case of a pandemic (Yesilyurt, 2020: 78). Tourism, transportation and food and beverage sectors which are called as the service sector; are the sectors most affected by this crisis. The cessation of the companies operating in this field caused the supply chain members operating in this field to not manage their demand and supply balances well. A significant decrease was observed in the non-food consumer products sector, especially in furniture and decoration, stationery, clothing and accessories expenditures (TEPAV, 2021).

The continuous change and development of technology day by day has led to the emergence of different business potentials for companies. Especially communication technology offers companies international market opportunities. While these developments in the technology world create job opportunities in different markets, the supply chain also changes in accordance with the changing conditions. Therefore, companies benefit effectively from the internet-based supply chain. The electronic supply chain is a platform where companies can perform their procurement, production and logistics activities more quickly during the Covid-19 pandemic, collaborate with other companies on this chain and provide cost savings by sharing information. For this reason, meeting the requests and requirements of the people in the electronic environment during the pandemic period has been a great advantage in terms of both the procurement activities of the companies and the fulfillment of the requests of the people. During Covid-19, e-supply chain management has been the most emphasized and spoken management system throughout its history.

\section{Conclusion}

One of the most important channels through which Covid-19 deeply affects the global economy is supply chain networks. After Covid-19, there are disruptions in the functioning of global procurement, which has created spillover effects at different levels in supplier networks. For example, automotive companies have had to stop their production due to a lack of parts, as in many different industrial sectors. Even in luxury items such as Swiss watches, manufacturers have faced a shortage of parts. These negativities in supply chains have increased the cost of work for manufacturing companies. Manufacturers that supply almost $70 \%$ of their products from China are on the brink of bankruptcy. As factories in China closed and transportation routes collapsed, it has become increasingly difficult to market products around the world. $75 \%$ of companies in the USA announced that there are distuptions in their supply chains. Many US companies have doubled their lead times from routine (Taylor and Schwartz, 2020).

After Covid-19, there was a shortage of raw materials and final products in the world. The insufficiency of air and sea transportation options has exacerbated the problems. As the virus infects even more countries, the interest and demand for Chinese products has decreased, which has revealed the fear of recession. Many different countries have started to implement risk reduction strategies due to the high costs that arise. It is very difficult to manage these risks by a single company. Therefore, supply chain risk management has been developed to manage risks in a wider scope. There are many types of risks that must be managed by the supply chain. These are risks that occur in different types such as natural disasters, hurricanes, pandemics, war, fire and flood. The COVID-19 virus, which the whole world lives, is just one of these risks. Although the expectation of pandemics is known by both governments and companies, the low probability of realization has created difficulties in terms of evaluating these risks. Many companies around the world have not been able to manage their supply chains against the pandemic and have faced significant disruptions. There were difficulties in meeting the needs, especially health and food supplies. This situation shows that supply chains are not ready for the pandemic and cannot cope with this situation. 


\section{References}

Aktas, E., (2010). Tedarik Zinciri Sözleşmelerinin Modellenmesi ve Bir Uygulama, İstanbul

Aysan A., Balcı E., Karagöl E., (2020). Covid 19 Pandemi Değerlendirme Raporu. Türkiye Bilimler Dergisi, Ankara.

Charles, C. P., (2003). Using Models to Improve the Supply Chain, St. Luice Press.

Chou, N. F., et al., (2004). Potential Impacts of the SARS Outbreak on Taiwan's Economy. Asian Economic Papers

Cinel, E., (2020). Covid-19’un Küresel Makroekonomik Etkileri ve Beklentiler, Politik Ekonomik Kuram, Giresun

Çengel, Ö., (2008). Tedarik Zinciri Yönetimi ve Lojistik Sektöründe Bir Araştırma, Bigart Yayınları.

Douglas M. Lambert, M. C., (1998). Supply Chain Management: Implementation Issues and Research Opportunities, The International Journal of Logistics Management, 9 (2), 1.

Erdal M., (2011). Satın Alma Ve Tedarik Zinciri Yönetimi, Beta Yayımevi, İstanbul.

Koçogłu, I., (2010). Tedarik Zinciri Yönetiminde Yenilik ve Bilgi Paylaşımının Önemi, Yüksek Lisans Tezi, Gebze Yüksek Teknoloji Enstitüsü Sosyal Bilimler Enstitüsü, Gebze.

Kulkarni, S.,(2001). Supply Chain Management:Creating Linkages for Faster Business Turnaround, Tata McGraw-Hil Lancioni, R., (2000). The Role of the Internet in Supply Chain Management, McGraw-Hill, New York. Lee A

Sar1, H.,Yeni emtia koruyucu maske. Date Of Access: 5 January 2021, https://www.dunya.com/dunya/yeni-emtiakoruyucu-maske haberi-466260.

Schmelz, D., Bizzari, A., Graham, R., Howdyshell, C.,( 2001). Business to buseiness online purchasing: suppliers impact on buyers adoptaion and usage internet, Journal of Supply Chain Managemen

Taylor, D. and Schwartz, J., Volkswagen Suspends Production as Coronavirus Hits Sales. Reuters. Date Of Access: 3 January 2021 https://www.reuters.com/article/us-volkswagen-results- 2019/volkswagen-suspends-production-ascoronavirus-hits-sales-idUSKBN2140OF.

TEPAV, COVID-19'un tüketici harcamalarına etkisi. Date Of Access: 2 January 2021, https://www.tepav.org.tr/tr/haberler/s/10110.

Ungan, M., (2011). Cahit., En Tyi Tedarik Zinciri Uygulamaları Ve Bir Saha Çalışması, Süleyman Demirel Üniversitesi Iktisadi ve Idari Bilimler Fakültesi Dergisi, C.16, S.2.

Üstün Ç., Özçiftçi S., (2020). COVID-19 Pandemisinin Sosyal Yaşam ve Etik Düzlem Üzerine Etkileri: Bir Değerlendirme Căalışması, Ege Üniversitesi Tıp Fakültesi, İzmir.

WHO. (2020). Coronavirus disease 2019 (COVID-19) Situation Report - 52. https://www.who.int/docs/defaultsource/coronaviruse/situation-reports/20200312-sitrep- 52-covid-19.pdf?sfvrsn=e2bfc9c0_4. Date Of Access: 10 February 2020.

Yeşilyurt, E.F., Oyak Renault'dan Koronavirüse karşı mücadeleye destek. Date Of Access: 5 January 2021, https://www.aa.com.tr/tr/sirkethaberleri/otomotiv/oyak-renault- dan-koronaviruse-karsi-mucadeleyedestek/656589.

Yld1z, Y., Otomotiv üretimine korona darbesi. Date Of Access: 5 January 2021, https://www.haberturk.com/otomotiv-uretimine-korona-darbesi-haberler-2620226- ekonomi. 